\title{
Comparison of the responses of some New Zealand and Australian honey bees (Apis mellifera $L$ ) to Nosema apis Z
}

\author{
LA Malone, HA Giacon, MR Newton \\ Horticulture and Food Research Institute of New Zealand Ltd, Mt Albert Research Centre, \\ Private Bag 92 169, Auckland, New Zealand
}

(Received 5 April 1995; accepted 31 August 1995)

\begin{abstract}
Summary - To determine whether the introduction of Carniolan stock may alter the impact of Nosema apis on New Zealand bees, the responses of Italian (Apis mellifera ligustica) and dark (Apis mellifera mellifera) New Zealand bees and Carniolan (Apis mellifera carnica) bees from Australia to dosing with $N$ apis spores were compared. Newly emerged adult bees were individually dosed with $2 \times 10^{5}$ $N$ apis spores, caged together in groups of 50 , and incubated at $33^{\circ} \mathrm{C}$. The longevity of each bee and number of $N$ apis spores carried by each bee at the time of death were recorded. All bees dosed with $N$ apis spores had significantly reduced longevity compared with the undosed control bees. Furthermore, there were no significant differences among the 3 stocks of bees in the degree of this reduction in longevity. However, dark and Carniolan bees survived better in cages than Italian bees, whether dosed or not. There were significant differences among the 3 stocks in the mean numbers of spores carried by each dosed bee at the time of death, with Italian bees carrying the highest spore loads, Carniolan bees the lowest, and dark bees carrying an intermediate number of spores. Thus, Carniolan bees from Australia may support a slower rate of $N$ apis proliferation and thus have lighter infections than New Zealand dark or Italian bees receiving similar doses of spores.
\end{abstract}

Nosema apis / honey bee / race / stock / longevity / spore load

\section{INTRODUCTION}

In New Zealand, only 2 races of the honey bee, Apis mellifera $\mathrm{L}$, are represented (Matheson, 1984); beekeepers use bees of the Italian race ( $A$ mellifera ligustica) and there are feral colonies of the dark bee $(A$ mellifera mellifera). Hybrids between the 2 are common. In Australia, the situation is similar, but Carniolan bees ( $A$ mellifera carnica) are also kept (DL Anderson, personal communication). In both countries, Nosema apis $\mathrm{Z}$ is a common pathogen with significant impact on honey production, pollination and bee breeding operations (Hornitzky, 1985; Anderson and Giacon, 1992).

The susceptibilities of the 3 different races of honey bees in Australia and New 
Zealand to $N$ apis infection have not been specifically compared. In New Zealand, we have found that colonies of Italian, dark and hybrid bees have similar responses to dosing with $N$ apis spores (Malone et al, 1992). Foraging bees sampled between 2 and 5 weeks after the colonies had been dosed had heavy $N$ apis infections. Bees taken from the same colonies between 6 and 12 weeks had lighter infections, comparable to those found in undosed, control colonies. There were also no significant differences among these colonies in laboratory-based tests. Here the rate at which $N$ apis infection spread from bee to bee was estimated by dosing one worker bee, caging it with several others and then determining infection levels after 1 or 2 weeks. Ruttner and Mackensen (1952) note a report by Goetze (1949) of bees with improved resistance to $N$ apis resulting from a cross between dark queens and Carniolan drones, but do not give details. Gromisz and Bobrzecki (1984) reported that 'local' Polish bees have better resistance to $N$ apis than Caucasian or Carniolan bees. There are no other published accounts of comparisons of the responses of the different races of stocks of $A$ mellifera bees to $N$ apis.

New Zealand beekeepers are currently debating whether or not to introduce Carniolan bees to this country (Stevenson, 1994a). Proponents of this move list the reputation of Carniolan bees for better resistance to mites and diseases as one of their desirable features (Stevenson, 1994b). However, recent research suggests that these bees may be more susceptible than Italian bees to Varroa jacobsoni mites (Rosenthal et al, 1991) and the chalkbrood fungus, Ascosphaera apis (Chang et al, 1989). To determine whether the introduction of Carniolan stock may alter the impact of $N$ apis on New Zealand bees, we compared the responses of Italian and dark bees from New Zealand and Carniolan bees from Australia to $N$ apis infection. A laboratory-based method was used, in which the longevities and final spore loads of bees dosed individually with $N$ apis spores and kept in cages were measured.

\section{MATERIALS AND METHODS}

Bees were obtained from 3 sources: a colony headed by an artificially inseminated Italian queen bee obtained from a New Zealand commercial bee breeder; a colony headed by a feral, naturally mated dark queen bee collected from a remote New Zealand site (North Hokianga) where dark bees predominate; and a frame of sealed brood from an Australian colony headed by a Carniolan queen bee obtained from an Australian commercial bee breeder. This frame was sent to us in a sealed, insulated container by air and all experiments with Australian bees were carried out under strict quarantine conditions in compliance with New Zealand Ministry of Agriculture and Fisheries regulations. All bees were destroyed at the end of the experiment.

To verify the races of bees represented by the 3 sources, the colour markings on the abdomens were noted and the cubital index, which is a ratio of the lengths of the long and short portions of the basal vein of the third cubital cell of the forewing, determined for 50 bees from each source. The colour markings were as expected for Italian, dark and Carniolan bees (see Ruttner, 1988), and the mean cubital indices were $2.61 \pm 0.07$ (range: $1.88-4.50$ ) for Italian bees, $1.97 \pm 0.04$ (range: $1.33-2.67$ ) for dark bees and $2.19 \pm 0.03$ (range: $1.80-3.00$ ) for Carniolan bees (fig 1). These measurements suggested that the Carniolan bees were not pure, according to the standards set by the Breeding Regulations of the German Beekeeper's Association (Ruttner, 1988), and that the sample may have included some dark/Carniolan hybrids. The mean cubital index for New Zealand Italian bees was within the range defined by Ruttner (1988) for A $m$ ligustica, but the mean index for New Zealand dark bees was higher than that listed for $A \mathrm{~m} \mathrm{mel-}$ lifera, suggesting that this sample may have included some Italian/dark hybrids.

A suspension of spores of $\mathrm{N}$ apis was prepared by freezing infected bees from our apiary at $\mathrm{Mt}$ Albert, Auckland, and crushing the cadavers in distilled water. This homogenate was then filtered through nylon mesh ( $10 \mu \mathrm{m}$ pore size) and the 
resulting suspension cleaned by 3 rounds of centrifugation and resuspension in distilled water. The spore concentration was estimated by a haemacytometer count and the suspension stored at $4^{\circ} \mathrm{C}$.
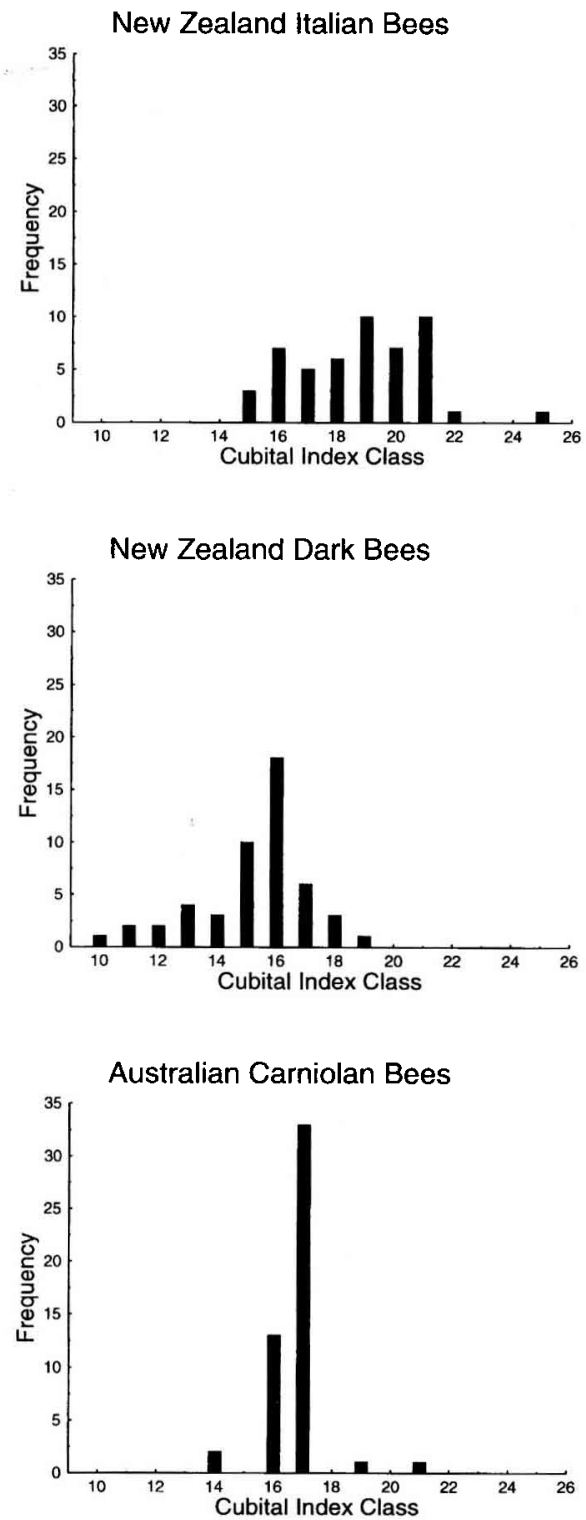

Fig 1. Frequency histograms of cubital indices for New Zealand Italian, New Zealand dark, and Australian Carniolan bees. Cubital index classes are as defined by Ruttner (1988).
All experiments were carried out in a controlled-temperature quarantine room at $33^{\circ} \mathrm{C}$. One frame containing capped brood of each of the 3 types of bees was brought into the room over a 2 week period and any emerged adult bees on these frames were destroyed immediately. To avoid the possibility of contamination with $N$ apis spores on the frames or in the wax, the cappings of cells containing newly emerging adult bees were carefully removed and about 100 bees collected from each frame over a period of $20 \mathrm{~min}$. Fifty bees of each type were dosed within $1 \mathrm{~h}$ of emergence by force-feeding each with $2 \mu$ of $60 \%(w / v)$ sucrose solution containing $2 \times 10^{5}$ $N$ apis spores. To do this, each bee was held with its mouthparts touching a $2 \mu \mathrm{l}$ droplet at the tip of a micropipette until it had consumed the entire droplet. The 50 remaining control bees each received $2 \mu$ of plain sucrose solution. Each group of 50 bees was confined to a cage $9 \times 8 \times$ $6 \mathrm{~cm}$ (internal dimensions), constructed from plywood ( 4 sides with holes for gravity feeders) and stainless steel mesh ( 2 sides) (for a photograph of a similar cage see Kulincevic et al, 1973). Each cage was kept at $33^{\circ} \mathrm{C}$ and bees were provided, ad libitum, with water and a $60 \%$ (w/v) sucrose solution via gravity feeders. In addition, a dietary supplement consisting of sodium caseinate $(0.12$ parts), brewer's yeast ( 0.24 parts) and sucrose (0.64 parts) mixed with water to a paste, was placed in each cage. Water, sucrose solution and supplement were replenished as necessary. Each cage was checked daily and any dead bees counted, removed and stored frozen. The $N$ apis spore load carried by each bee at the time of death was estimated by thawing each cadaver, crushing it thoroughly in $0.5 \mathrm{ml}$ of distilled water, examining each microscopically and counting any spores using a haemacytometer. The experiment was repeated 4 times for each type of bee within $2 \mathrm{~d}$ of the frame being brought into quarantine, using different groups of bees.

Longevity results for each type of bee and each replicate were plotted as percent of bees surviving vs time after dosing (fig 2). $F$ tests for analysis of variance were conducted to compare the 3 types of bees and the 4 replicates at $5 d$ intervals throughout the duration of each experiment. Comparisons were made for: (i) the differences in survival between control and dosed bees; (ii) the survival of control bees; and (ii) spore loads carried by dosed bees. 


\section{RESULTS}

Figure 2 shows that, for each of the 3 stocks of bees, individuals dosed with $N$ apis spores died earlier than the control bees $(P \leq 0.01)$ and that this reduction in longevity was of a similar magnitude for each stock (ANOVA, no significant differences among replicates).

However, figure 2 also shows that there were differences among the 3 different stocks in the abilities of both dosed and control bees to survive in cages. After $30 \mathrm{~d}$ in cages, undosed New Zealand dark bees and Australian Carniolan bees were found to survive better than undosed New Zealand Italian bees ( $P \leq 0.01$, ANOVA, no significant differences among replicates). Likewise, $N$ apis-dosed dark and Carniolan bees lived longer than dosed Italian bees. Thus, the Italian bees had the poorest survival when dosed with $N$ apis, but this may have been because of their relatively poor ability to survive in cages rather than a direct result of their response to $N$ apis dosing.

There were marked differences among the 3 types of bees in the mean numbers of $N$ apis spores carried by each dosed bee at the time of death (table I), with Italian bees carrying the highest spore loads, Carniolan bees the lowest, and dark bees carrying an intermediate number of spores. Analysis of variance showed that these differences were significant for all bees dying 15 or more days after dosing $(P \leq 0.01$, ANOVA, no significant differences among replicates). None of the control bees were infected.

\section{DISCUSSION}

As has been noted in other studies (Rinderer and Sylvester, 1978), dosing with $N$ apis significantly reduced the longevity of all the bees used in this study. This effect was par- ticularly noticeable in bees dying after about 20 d. Wang and Moeller (1970) noted that $N$ apis-infected bees in an observation hive
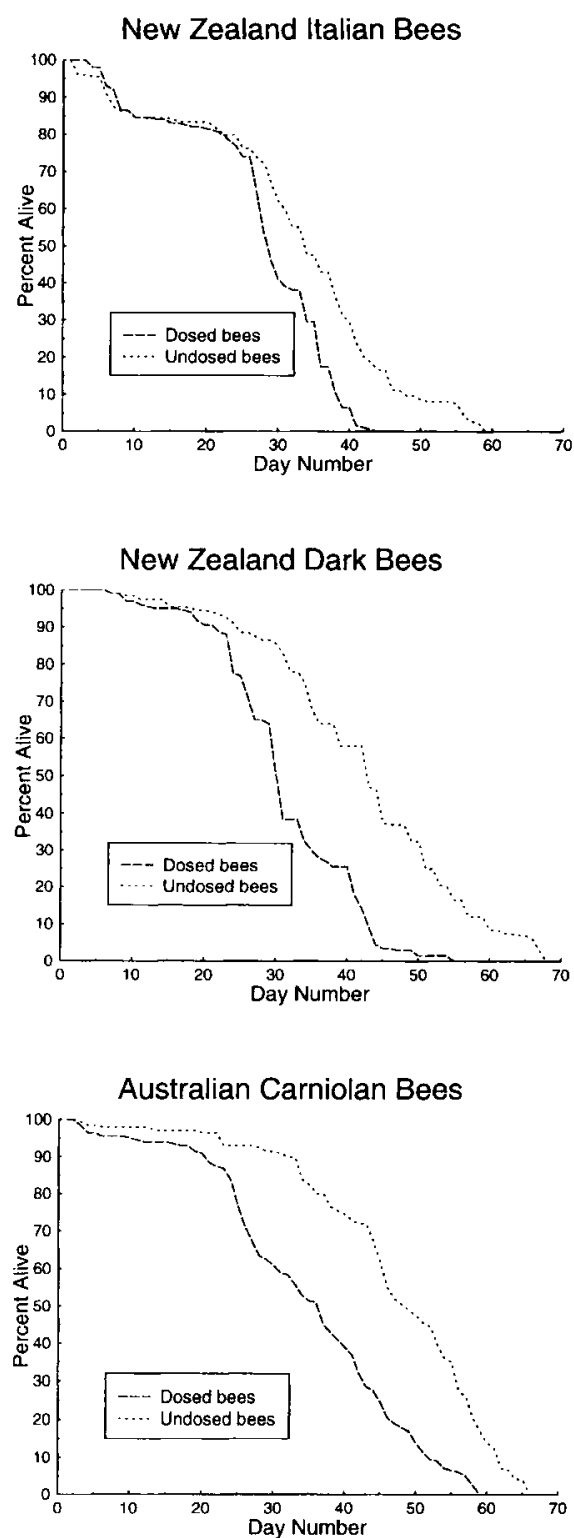

Fig 2. Effect of $N$ apis dosing on the survival of New Zealand Italian, New Zealand dark, and Australian Carniolan bees (pooled results of 4 replicates). 
Table I. Mean numbers of $N$ apis spores carried at the time of death by dosed bees of 3 different stocks.

\begin{tabular}{|c|c|c|c|}
\hline Stock & Country of origin & Number examined & Millions of spores per bee $(\text { mean } \pm S E)^{a}$ \\
\hline Italian & New Zealand & $\begin{array}{l}200^{b} \\
166^{c}\end{array}$ & $\begin{array}{l}44.89 \pm 3.53^{b} \\
53.75 \pm 3.92^{c}\end{array}$ \\
\hline Dark & New Zealand & $\begin{array}{l}200^{b} \\
190^{c}\end{array}$ & $\begin{array}{l}31.91 \pm 3.16^{b} \\
33.42 \pm 3.29^{c}\end{array}$ \\
\hline Carniolan & Australia & $\begin{array}{l}200^{b} \\
188^{c}\end{array}$ & $\begin{array}{l}12.74 \pm 1.18^{b} \\
13.56 \pm 1.23^{c}\end{array}$ \\
\hline
\end{tabular}

a $S E$ is standard error of the mean; ${ }^{b}$ all bees; ${ }^{c}$ bees dying more than $15 \mathrm{~d}$ after dosing only.

"generally do not live beyond $15 \mathrm{~d}$ ". This difference may be attributable to the relative inactivity (no flight) of bees in cages compared to those kept in hives. There were no significant differences noted in the present study among the 3 different types of bees in terms of the size of the infection-induced reduction in longevity, ie bees from all stock responded to dosing with a similar decrease in longevity. However, the superior ability of the dark and Carniolan control bees to survive in cages was retained even after dosing (fig 2).

Bees confined to cages have been shown to have elevated levels of juvenile hormone, similar to those found in older foraging bees in a colony (Robinson, 1994). This suggests that, in a physiological sense, caged bees age prematurely and bypass the 3-week nursing phase. The dark and Carniolan bees may take longer to undergo this process or they may simply withstand the elevated juvenile hormone levels better than the Italian bees. A comparison of longevities of foraging bees of different races under field conditions would help to determine whether our observations with caged bees were a result of a fundamental racial difference in adult bee life spans. Khanbash (1989) found that Carniolan bees in a trial in Hungary gathered more pollen per day than Italian bees, but did not compare foraging lifetimes of these bees.

Carniolan bees also carried fewer $N$ apis spores at the time of death than the dark bees, which in turn carried fewer than the Italian bees. This suggests that the pathogen may multiply at a different rate in each of the 3 stocks, although a more detailed examination of the progress of infections is needed to confirm this. The dark bees carried significantly more $N$ apis spores than the Carniolan bees, even though both stocks had similar longevity under these conditions. This suggests that the dark bees may tolerate $N$ apis infection better than the Carniolan bees. Further experimentation is needed to determine whether these differing spore loads reflect the operation of some resistance or tolerance mechanisms. Regardless of this, differing spore loads do have implications for the potential of each infected bee to contribute to $N$ apis inoculum levels in the hive and nearby environment, either by defaecation of spores or by their release from the adult cadaver. As Carniolan bees die with the lowest spore loads, the numbers of spores available for infection of further bees are less than for dark and Italian bees. 
In this sense, Carniolan bees may not be as affected by $N$ apis as the bees which we currently use in New Zealand.

Because of quarantine requirements, each stock of bees examined in the present study was represented only by a single colony, so that we cannot be certain that the differences observed were representative of the 3 races. Also, the cubital index measurements suggested the presence of some hybrids in our samples. However, no significant differences in survival or spore loads were found in previous experiments using similar methods to compare the effects of $N$ apis dosing on 7 inbred lines of New Zealand Italian race bees (unpublished observations). Field experiments with Italian and dark bees from 13 different New Zealand sources also failed to reveal any colony differences (Malone et al, 1992). These observations suggest that the significant differences noted in the present study may be due to racial, rather than colony, differences.

Further studies are warranted to compare different races of bees, using pure Carniolans in place of the impure line used here, and examining other bee responses, such as flight activity and foraging ability, in addition to longevity and spore loads. Field studies to compare colony performance would also be valuable, but, because of quarantine restrictions, these would have to be conducted outside New Zealand.

\section{ACKNOWLEDGMENTS}

We wish to thank D Yanke of Daykel Apiaries, Kaitaia, New Zealand and R Rice and D Anderson of CSIRO, Canberra, Australia for supplying us with bees for this experiment. We also thank $J$ Maindonald of the Horticulture and Food Research Institute of New Zealand for statistical analysis and advice. This work was supported by the Foundation for Research, Science and Technology, New Zealand (C06204).
Résumé - Comparaison des réponses d'abeilles néo-zélandaises et australiennes à Nosema apis Z. On a comparé les réponses d'abeilles néo-zélandaises Apis mellifera ligustica (abeille italienne) et Apis mellifera mellifera (abeille noire) et d'abeilles australiennes de race carniolienne Apis mellifera carnica à des spores de Nosema apis. Les colorations des abeilles étaient conformes à celles attendues pour les 3 races, et l'index cubital moyen était de $2,61 \pm 0,07$ (écart : $1,88-4,50$ ) pour les abeilles italiennes, de 1,97 $\pm 0,04$ (écart : $1,33-2,67$ ) pour les abeilles noires et $2,19 \pm 0,03$ (écart : $1,80-3,00$ ) pour les abeilles carniolennes (fig 1). Ces mesures suggèrent que les abeilles carnioliennes n'étaient pas pures mais que certaines étaient des hybrides d'abeilles noires et carnioliennes, et également que l'échantillon d'abeilles noires de Nouvelle-Zélande comportait des hybrides d'abeilles noires et d'abeilles italiennes. On a administré à des abeilles émergentes de chaque race $2 \mathrm{x}$ $10^{5}$ spores de $N$ apis, puis elles ont été encagées par groupe de 50 et placées à l'étuve à $33^{\circ} \mathrm{C}$. L'expérimentation a été répétée 4 fois et la longévité des abeilles ainsi que le nombre de spores portées par chacune d'elles au moment de sa mort ont été enregistrés. L'administration de $N$ apis réduit significativement la longévité des abeilles de chacune des 3 races. Cependant les différences entre les races n'étaient pas significatives (ANOVA) (cffig 2). Pour les abeilles témoins non-infestées, après 30 j en cage, les abeilles noires de Nouvelle-Zélande et les abeilles carnioliennes australiennes sont plus nombreuses à survivre que les abeilles italiennes de Nouvelle-Zélande $(p<0,01$, ANOVA). De même, chez les abeilles infestées, les abeilles noires et carnioliennes ont davantage survécu que les abeilles italiennes (fig 2). II y eut des différences marquées entre les 3 races dans le nombre moyen de spores de $N$ apis portés par chaque abeille au moment de sa mort (tableau I), avec les abeilles italiennes por- 
tant le nombre le plus élevé de spores, les carnioliennes le nombre le plus faible, et les abeilles noires un nombre intermédiaire. L'analyse de variance a montré que ces différences étaient significatives pour toutes les abeilles mourant $15 \mathrm{j}$ ou plus après l'infestation ( $p<0,01$, ANOVA). Aucune des abeilles témoins n'a été infestée. Ainsi, les abeilles carnioliennes d'Australie qui reçoivent la même quantité de spores que les abeilles noires ou italiennes de Nouvelle-Zélande ont un taux d'infestation plus faible.

\section{Nosema apis / Apis mellifera / race /} lignée / longévité / spores

\section{Zusammenfassung - Vergleich von Reaktionen einiger neuseeländischer und australischer Honigbienen (Apis mellifera $\mathrm{L}$ ) auf Nosema apis Z. Die Reak-} tion von italienischen (Apis mellifera ligustica) und dunklen Bienen (Apis mellifera mellifera) aus Neuseeland und von CarnicaBienen (Apis mellifera carnica) aus Australien auf dosierte Infektionen mit Nosema apis Sporen wurden miteinander verglichen. Die Farbmerkmale dieser Rassen entsprachen den Erwartungen. Der mittlere Kubitalindex betrug bei den italienischen Bienen $2,61 \pm 0,07$ (Bereich 1,88-4,50), bei den dunklen Bienen 1,97 $\pm 0,04$ (Bereich: 1,33-2,67) und bei den Carnica-Bienen 2,19 $\pm 0,03$ (Bereich: 1,80-3,00; Abb 1). Diese $\mathrm{Maße}$ weisen darauf hin, daß die CarnicaBienen nicht rein waren, sondern daß sich in der Probe wahrscheinlich auch einige me/lifera/carnica Hybriden befunden haben. Auch die Probe der dunklen Bienen von Neuseeland könnte ligustica/mellifera Hybriden enthalten haben. Frisch geschlüpfte Arbeiterinnen von jeder Herkunft wurden individuell mit einer Dosis von $2 \times 10^{5}$ Nosema apis Sporen infiziert. Sie wurden in Gruppen von 50 gekäfigt und bei $33^{\circ} \mathrm{C}$ im Brutschrank gehalten. Die Lebensdauer der Bienen und die Anzahl der Sporen in jeder Biene wurde bei ihrem Tod notiert. Dieser Versuch wurde vier mal wiederholt. Eine Infektion mit $N$ apis verkürzte die Lebensdauer der Bienen bei allen drei Herkünften. Es gab jedoch keine signifikanten Unterschiede zwischen den drei Herkünften in der Verkürzung der Lebensdauer (ANOVA; Abb 2). Unbehandelte dunkle Bienen aus Neuseeland und Carnica-Bienen aus Australien haben 30 Tage im Käfig besser überlebt als unbehandelte italienische Bienen aus Neuseeland (ANOVA; $P \leq 0,01$ ). Entsprechend lebten auch die mit $N$ apis infizierten dunklen und Carnica-Bienen länger als infizierte italienische Bienen (Abb 2). Deutliche Unterschiede gab es zwischen den 3 Herkünften in der beim Absterben in den einzelnen Bienen vorhandenen Sporenzahl von $N$ apis (Tabelle I). Die italienischen hatten die höchste Sporenmenge, die Carnica-Bienen die niedrigste und die dunklen Bienen hatten eine mittlere Anzahl. Eine Varianzanalyse zeigte, daß diese Unterschiede bei allen Bienen signifikant waren, die 15 Tage nach der Infektion oder noch später starben (ANOVA; $p \leq 0,01$ ). Keine der Kontrollbienen war infiziert. Demnach könnten Carnica-Bienen aus Australien die Verbreitungsrate von $N$ apis vermindern und bei gleicher Infektionsdosis mildere Infektionen haben als die dunklen oder italienischen Bienen von Neuseeland.

Nosema apis / Honigbiene / Rasse / Herkunft / Lebensdauer / Sporenmenge

\section{REFERENCES}

Anderson DL, Giacon H (1992) Reduced pollen collection by honey bee (Hymenoptera: Apidae) colonies infected with Nosema apis and sacbrood virus. $J$ Econ Entomol 85, 47-51

Chang YD, Yim YH, Cho YH, Lee MY (1989) The rate of infection by Ascosphaera apis Olive and Spiltoir in different races, population levels and developmental stages of honeybees. Korean J Apicult 4, 81-84

Goetze G (1949) Imkerliche Züchtungspraxis. Landbuch-Verlag, Hannover 
Gromisz M, Bobrzecki J (1984) Comparison of the performance of three honeybee races in the Olsztyn (NE Poland) region. Pszczelnicze Zeszyty Naukowe 28, 85-99

Hornitzky M (1985) Major bee diseases in Australia. Australian Standard Diagnostic Techniques for Animal Diseases No 35, $17 \mathrm{p}$

Khanbash $M$ (1989) The relationship between population size and amount of pollen collected by Carniolan and Italian honey bee colonies. Debreceni Agrartudomanyi Egyetem Tudomanyos Kozlemenyei 28, 179-195

Kulincevic JA, Rothenbuhier WC, Stairs GR (1973) The effect of presence of a queen upon outbreak of a hairless-black syndrome in the honey bee. $J$ Invertebr Pathol 21, 241-247

Malone LA, Giacon HA, Hunapo RJ, Mclvor CA (1992) Response of New Zealand honey bee colonies to Nosema apis. J Apicult Res 31, 135-140

Matheson A (1984) Practical Beekeeping in New Zealand Government Printer, Wellington, New Zealand

Rinderer TE, Sylvester HA (1978) Variation in response to Nosema apis, longevity, and hoarding behavior in a free-mating population of the honey bee. Ann Entomol Soc Am 71, 372-374

Robinson GE (1994) Regulation of division of labor in honey bee colonies: integrated hormonal, genetic, and neural analyses of social behavior. In: Proceedings of the 12th Congress of the International Union for the Study of Social insects IUSSI, 21-27 August, 1994, Sorbonne, Paris, France (A Lenoir, G Arnold, M Lepage, eds), Université Paris-Nord

Rosenthal C, Efrat H, Kamer I, Ron M (1991) A comparative study between Varroa's dynamics for Italian versus Carniolan bees. In: Proceedings of the International Symposium on Recent Research on Bee Pathology, September 5-7, 1990, Ghent, Belgium (W Ritter, ed) Bd Merelbeke, Belgium, on behalf of Apimondia

Ruttner F (1988) Breeding Techniques and Selection for Breeding of the Honeybee. The British Isles Bee Breeders Association by arrangement with Ehrenwirth Verlag, Munich, Germany

Ruttner F, Mackensen $O$ (1952) The genetics of the honey bee. Bee World 33, 71-79

Stevenson B (1994a) Industry votes to debate Carniolan imports. NZ Beekeeper 1, 6-7

Stevenson B (1994b) Carniolans: what are they, does the $\mathrm{NZ}$ industry need them, what are the risks? NZ Beekeeper 1,8

Wang Der-l, Moeller FE (1970) The division of labor and queen attendance behavior of Nosema-infected worker honey bees. J Econ Entomol 63, 1539-1541 